\title{
Multidimensional Internationalization Speed and Firm Performance: Evidence from the Indonesian Manufacturing
}

\author{
Joseph. Susanto ${ }^{1,}$ Deddy Marciano ${ }^{2, *} \&$ Arif Herlambang ${ }^{3}$ \\ ${ }^{1}$ University of Surabaya, Surabaya, Indonesia \\ ${ }^{2}$ University of Surabaya, Surabaya, Indonesia \\ ${ }^{3}$ University of Surabaya, Surabaya, Indonesia \\ *Corresponding author. Email: marciano@staff.ubaya.ac.id
}

\begin{abstract}
This study aims to determine the impact of multidimensional internationalization speed on firm performance on the manufacturing firm listed on the Indonesian Stock Exchange over the 2015-2019 period. The dependent variables in this study are return on assets and Tobin's $\mathrm{q}$, while the independent variables used are speed of change in the breadth of international markets, speed of change in international commercial intensity, and speed of change in the commitment of foreign resources. Then, control variables are firm size, firm age, rhythm, and regional concentration. This study used a multiple regression method to test the hypothesis consist of 43 Indonesian manufacturing firms. The number of observations used in this study was 215 observations at first by using classical. This study demonstrates that speed of change in the breadth of international markets has a positive but curvilinear effect on return on assets and has a negative but curvilinear effect on Tobin's Q. Meanwhile, speed of change in international commercial intensity has a positive but curvilinear effect on return on assets and no significant effect on Tobin's Q. Finally, speed of change in the commitment of foreign resources has a positive but curvilinear effect on both return on assets and Tobin's Q.

Keywords: multidimensional, speed, internationalization, performance, TCD.
\end{abstract}

\section{INTRODUCTION}

In this modern world, the industry has developed into industry 4.0 (Kagermann et al. 2013). Industrial development has also made information technology more open, making it easier for a firm to carry out operational activities and strategic decisions (Strange \& Zucchella 2017). This condition can initiate a domestic firm to integrate into the current global economy (Powell 2014). According to Penrose (1959), firms certainly have the primary goal of experiencing growth. One of the firm's strategies to experience growth is to expand overseas or international markets (Dunning \& Lundan 2008).

The problem faced by the firm now is how fast the firm can adequately internationalize to global markets (Mohr \& Batsakis 2017). The prospective international firm must realize that the internationalization progress brought benefits and costs for the firm and the relationship between internationalization and performance depend on the domination of benefits and costs of internationalization (Zhou 2018). Scholars still cannot find a breakthrough to solve this problem regarding the proper speed of internationalization for the firm to get more benefits than costs. 
Therefore, the speed of internationalization that a firm must undertake is still unsolved.

Speed has become attractive for many researchers in past decades. Hilmersson \& Johansson (2016) state that there are several shortcomings of explanation regarding the speed of internationalization conducted by previous researchers: Most studies only focus on explaining the starting phase of internationalization and less is analyzing the continuous phase. Researchers often treated internationalization as a unidimensional activity rather than as several different internationalization activities and carried out gradually and interrelated. Most research just tries to determine factors of rapid internationalization but not focusing on consequences like speed.

This study seeks to validate the multidimensional concept of the speed of internationalization, which was introduced by Casillas \& Acedo (2013) and then further developed by Hilmersson \& Johansson (2016), who succeeded in showing a comprehensive view of internationalization speed and its impact on firm performance in Swedish SMEs.

In a previous study, Eriksson et al. (1997) explained that every time a firm enters a foreign market using the knowledge previously mastered, the costs of entering the market are lower than at the beginning. The advantages of learning come from the fact that experience and knowledge shared between the firm's business units in foreign markets signifies that the need to learn will decrease during the process. This study is in line with the strategic theory of a resource-based view, which emphasizes that firm growth and performance can be tracked based on an experiential knowledge base (Helfat \& Peteraf 2003, Wernerfelt 1984). Furthermore, experiential knowledge becomes an intangible resource that can be a competitive advantage for a firm (Oviatt \& McDougall 2005). The sooner the firm can start increasing the exposure of its products to international markets, the better the firm can learn from that market, thus forcing the firm to adapt and develop routines and organiza- tional structures to suit international operations (Autio et al. 2000), which tends to have a positive impact on performance. Nevertheless, when the speed is too fast, there will be too much knowledge from the experience that is difficult to understand and apply directly to firm strategy. The international capability development process, which is accelerated drastically, has a negative impact on firm performance with an increase in costs (Dierickx \& Cool 1989).

H1: The firm's speed in increasing the breadth of in-ternational markets has a curvilinear effect on firm performance (inverted U-shaped).

Firms that intend to increase their export intensity tend to develop their routines and structures based on home market experiences. Adaptations made by the firm in sales in foreign markets are carried out to meet foreign market demand which subsequently becomes the firm's export strategy. Due to the high level of experience, the speed at which the international commercial intensity increases high gives the advantages of the small scale of its business and the novelty of its operations (Autio et al. 2000), which eases the firm to develop its international activities and provide improvements in firm performance because competitors have not recognized their existence. As explained above, when firms increase their international commercial intensity, they will face situations that require developing new capabilities and routines and leaving old routines (Barkema \& Vermeulen 1998). However, Hilmersson \& Johanson (2016) disagree and explain that firms that do not overhaul their current routine and structure instead focus on developing capacity related to their export growth by sticking to the cur-rent routine and structure. Faster international commercial intensity will lead to a situation where the firm's capabilities can be maintained at a relatively low cost. Based on the argument of TCD, when the speed of export intensity is accelerated dramatically, there will be a TCD effect and reduce firm performance. 
$\mathrm{H} 2$ : The firm's speed of growth in international com-mercial intensity has a curvilinear effect on firm per-formance (inverted Ushaped).

Several studies on the internationalization of firms demonstrate that the rapid and massive establishment of subsidiaries in foreign markets can have a negative effect on firm performance (Jiang et al. 2014, Vermeulen \& Barkema 2002). The complexity and magnitude of the commitment of resources mean that a large capacity tends to be needed to absorb the knowledge received in achieving and receiving benefits quickly and massively (Cohen \& Levinthal 1990). A firm that only experiences foreign markets for a short period cannot transform the experiences gained into useful knowledge (Vermeulen \& Barkema 2002, Wagner 2004). Firms that have rigid routines and structures accompanied by the aspiration to become big and increase their resource commitment will have a negative effect on firm performance. According to the logic of TCD (Dierickx \& Cool 1989), the more knowledge that must be absorbed in a short time will result in higher cost. Hilmersson \& Johan-son (2016) state that a firm can experience absent revenues or revenues that become uncertain and difficult to obtain when learning new things is pressed to be shorter. Even simultaneously, the advantages of the rapid and massive development of flexible routines and capabilities for internationalization still cannot compensate for the increase in TCD. According to Hilmersson \& Johanson (2016), there are two rea-sons for this effect. First, the firm is less likely to in-vest significantly in capital over a short period unless there is a commensurate profit opportunity. Second, increasing the scale of production and distribution in order to support the speed of internationalization re-quires high costs.

H3: The firm's speed in increase the commitment of resources to foreign activities has a curvilinear effect on firm performance (Ushaped).

This study adds one dependent variable, Tobin's Q. R. García et al. (2017) explain that long-term performance is a more accu- rate result than that used in previous researchers for two reasons. First, it cap-tures the consequences of a rapid internationalization more rigorously than accounting measures, which have a short-term orientation. Second, it is a better proxy of future growth prospects than survival measures since they do not discriminate among profitable investments.

\section{RESEARCH METHODS}

This study used multiple processing methods, both linear and polynomial, to determine the effect of the independent and control variables on the dependent variable. The variables used were two dependent variables, three independent variables, and four control variables. The dependent variables used were return on assets (ROA) and Tobin's q (TQ), while the independent variables in this study were the speed of increase in international breadth, the speed of growth in international commercial intensity, and the speed of increasing commitment of resources to foreign activities. The control variables are firm age, firm size, rhythm, and regionalization. The equation to be used in this study is as follows:

$$
\begin{aligned}
& \mathrm{ROA}_{i, t}=\alpha+\beta_{1} \mathrm{INTB}_{i, t}+\beta_{2} \mathrm{INTC}_{i, t}+ \\
& \beta_{3} \mathrm{INTI}_{i, t}+\beta_{4} \mathrm{FA}_{i, t}+\beta_{5} \mathrm{FS}_{i, t}+\beta \\
& { }_{6} \operatorname{Reg}_{i, t}+\beta_{7} \operatorname{Rtm}_{i, t}+\mathrm{C} \\
& \mathrm{TQ}_{i, t}=\alpha+\beta_{1} \mathrm{INTB}_{i, t}+\beta_{2} \mathrm{INTC}_{i, t}+ \\
& \beta_{3} \mathrm{INTI}_{i, t}+\beta_{4} \mathrm{FA}_{i, t}+\beta_{5} \mathrm{FS}_{i, t}+\beta \\
& { }_{6} \operatorname{Reg}_{i, t}+\beta_{7} \operatorname{Rtm}_{i, t}+\mathrm{C} \\
& \mathrm{ROA}_{i, t}=\alpha+\beta_{1} \mathrm{INTB}_{i, t}+\beta_{2} \mathrm{INTC}_{i, t}+\beta_{3} \mathrm{I} \\
& \mathrm{NTI}^{2}{ }_{i, t}+\beta_{4} \mathrm{INTB}^{2}{ }_{i, t}+\beta_{5} \mathrm{INTC} \\
& { }_{i, t}+\beta_{6} \mathrm{INTI}_{i, t}+\beta_{7} \mathrm{FA}_{i, t}+\beta_{8} \mathrm{FS}_{i} \\
& { }_{, t}+\beta_{9} \operatorname{Reg}_{i, t}+\beta_{10} \operatorname{Rtm}_{i, t}+\mathrm{C} \\
& \mathrm{TQ}_{i, t}=\alpha+\beta_{1} \mathrm{INTB}_{i, t}+\beta_{2} \mathrm{INTC}_{i, t}+\beta_{3} \mathrm{I} \\
& \mathrm{NTI}^{2}{ }_{i, t}+\beta_{4} \mathrm{INTB}^{2}{ }_{i, t}+\beta_{5} \mathrm{INTC} \\
& { }^{2}{ }_{i, t}+\beta_{6} \mathrm{INTI}_{i, t}+\beta_{7} \mathrm{FA}_{i, t}+\beta_{8} \mathrm{FS}_{i} \\
& { }_{, t}+\beta_{9} \operatorname{Reg}_{i, t}+\beta_{10} \operatorname{Rtm}_{i, t}+\mathcal{C}
\end{aligned}
$$

where ROA: return on assets; TQ: Tobin's Q; INTB: speed of increase in the breadth of international mar-kets; INTI: speed of growth of international commercial intensity; INTC: speed of increase in commitment 
of resources to foreign activities; FS: firm size; FA: firm age; Rtm: ryhthm; Reg: regionalization; e: standard deviation.

\section{RESULTS AND DISCUSSIONS}

This study used a research sample of manufacturing firms listed on the Indonesia Stock Exchange over the 2015-2019 period. The sample firms used were 43 firms and totaled 215 observations. This research initially wanted to test independent and control variables on the dependent variable using a linear regression model.

Table 1. Descriptive Statistics

\begin{tabular}{cccccc}
\hline Var & Min & Max & Mean & Median & Std. Dev. \\
\hline ROA & -0.2214 & 0.3002 & 0.0516 & 0.0416 & 0.0773 \\
TQ & 0.0082 & 12.7532 & 1.2917 & 0.5207 & 1.9075 \\
INTB & 0.0208 & 1.0000 & 0.2493 & 0.2222 & 0.1774 \\
INTI & 0.0000 & 0.1667 & 0.0224 & 0.0160 & 0.0252 \\
INTC & 0.0000 & 0.1023 & 0.0140 & 0.0083 & 0.0160 \\
FA & 0.0000 & 1.9031 & 1.2141 & 1.2788 & 0.3106 \\
FS & 4.3041 & 11.421 & 8.1953 & 8.1131 & 1.3955 \\
REG & 0.1709 & 1.0000 & 0.8222 & 0.9350 & 0.2140 \\
RTM & -6.0000 & 29.000 & 7.9236 & 5.9766 & 8.1444 \\
\hline
\end{tabular}

Table 1 presents the descriptive statistics for all variables. As seen in Table 1, the sampled firms display heterogeneous performance extending from $-22.14 \%$ to $30.02 \%$ in return on assets variables and 0.01 to 12.75 in Tobin's q over the studied period. The aver-age performance is $5.16 \%$ and 1.29. An interesting heterogeneity can also be seen in the three dimensions of internationalization speed. This heterogeneity circles the mean values, which indicates that, since inception, the average firm entered one new market per four years $(0.25)$, increased its international intensity $2.24 \%$ per year, and reallocated its resources to international activities at a rate of $1.4 \%$ per year.

Based on the results of hypothesis testing using a linear regression model from Table 2 , it can be seen that the two models show different results from one another. $\underline{\text { Table 2. Linear Regression Model }}$

\begin{tabular}{lllll}
\hline Var & \multicolumn{3}{c}{ ROA } & \multicolumn{2}{c}{ TQ } \\
& Coef & t-stat & Coef & t-stat \\
\hline INTB & 0.0155 & $2.0273 * *$ & -0.6599 & -1.1146 \\
INTI & 0.5347 & $4.7478 * * *$ & 3.8740 & 0.8785 \\
INTC & -0.0138 & -0.1984 & -1.8950 & -0.4787 \\
FA & -0.0164 & -1.2438 & -1.0654 & $-1.8281^{*}$ \\
FS & -0.0218 & -3.4674 & 0.1919 & 1.4275 \\
REG & 0.0160 & 0.7080 & 0.8506 & 1.4075 \\
RTM & -0.0014 & -2.3478 & 0.0140 & 0.7374 \\
N & 215 & & 215 \\
AdjR ${ }^{2}$ & 0.9615 & -0.0019 \\
\hline ** significant $\alpha=1 \%, * *$ significant $\alpha=5 \%, ~$ signif- \\
icant $\alpha=10 \%$
\end{tabular}

This is evidenced by the value of the coefficient of determination (adjusted Rsquared) for each of these models. According to Table 2, the coefficient of determination in model 1 shows that the ROA can be explained by INTB, INTI, INTC, FA, FS, REG, and RTM with a value of $96.15 \%$. However, model 2 shows the coefficient of determination in the amount of $0 \%$, where this value implies that the TQ cannot be explained by INTB, INTI, INTC, FA, FS, REG, and RTM. Both results are still unable to show the impact of the speed of internationalization on firm performance comprehensively, so this study decided to test using a polynomial regression model to find the curvilinear effect in the independent variables of this study.

Table 3. Polynomial Regression Model

\begin{tabular}{|c|c|c|c|c|}
\hline \multirow[t]{2}{*}{ Var } & \multicolumn{2}{|r|}{ ROA } & \multicolumn{2}{|r|}{ TQ } \\
\hline & Coef & t-stat & Coef & t-stat \\
\hline INTB & 0.0512 & $3.2655 * * *$ & $-0.8257-$ & $1.1146^{* * *}$ \\
\hline INTI & 0.6683 & $10.3172 * * *$ & 1.6988 & 0.8785 \\
\hline INTC & 0.1487 & -0.1984 & 0.6004 & $-0.4787 *$ \\
\hline INTB $^{2}$ & -0.0549 & $-2.5141 * *$ & 1.4898 & $-1.1146 * * *$ \\
\hline $\mathrm{INTI}^{2}$ & -0.0311 & $-2.2624 * *$ & -0.1766 & 0.8785 \\
\hline INTC $^{2}$ & -0.0249 & $4.8923 * * *$ & $-0.1210-$ & $2.3989 * *$ \\
\hline FA & -0.0170 & -1.3045 & -1.0654 & $-3.3131 * * *$ \\
\hline FS & -0.0215 & $-3.7320 * * *$ & 0.1919 & $-5.0408 * * *$ \\
\hline REG & 0.0203 & 0.7770 & 0.8506 & $6.9219 * * *$ \\
\hline RTM & -0.0015 & $-2.5308 * *$ & 0.0140 & -1.3132 \\
\hline $\mathrm{N}$ & & 215 & & 215 \\
\hline $\operatorname{AdjR}^{2}$ & & 0.9602 & & 0.9389 \\
\hline
\end{tabular}


From that test, Table 3 exhibits that the coefficient of determination from both models is better than be-fore, as seen from their current results above $90 \%$, and proves that there is a curvilinear effect on an in-dependent variable that affects the dependent variable. All the results in the regression table have their respective explanations related to the impact of the independent variables and their curvilinear effects and control variables on the dependent variable related to the object in this study.

Our findings reveal that the speed of increasing the breadth of international markets has an inverted u-shaped effect on firm performance, which is the return on assets. These results are in line with Hilmersson \& Johanson (2016). The sooner the firm can start increasing the exposure of its products to international markets, the better the firm can learn from that market, thus forcing the firm to adapt and develop routines and organizational structures to suit and suit international operations (Autio et al. 2000) where it tends to have a positive impact on firm performance. When firms constantly and massively increasing their size in the international market, they can slowly increase their international capabilities. However, when the speed of internationalization exceeds the limits of the firm's absorptive capacity, firm performance will decline due to the TCD effect (Autio et al. 2000).

With different determinants of firm performance measurement (Tobin's q), the result shows that the speed of increasing the breadth of international mar-kets has a ushaped effect on firm performance. These results are consistent with the "bonding" theory" conducted by Doidge et al. (2004), which shows a similar pattern of relationships. Chen et al. (2015) state that firms expanding their internationalization activities will face high initial costs (entry fees to new foreign markets) due to differences in culture, regulations, consumer behavior, and so on in these new markets; thus, prior learning is needed. However, the firm performance will get better and increase depending on its ability to continue improving its governance in a better direction.

Next, the speed of growth in international commercial intensity in this study has an inverted u-shaped effect on firm performance (return on assets). These results are consistent with research conducted by Autio et al. (2000). Firms with rapid growth rates in high international commercial intensity will benefit from learning from older firms related to the competencies required to pursue sustainable growth in foreign markets. A study done by Hilmersson \& Johansson (2016) shows a firm that does not overhaul its current routine and structure but focuses on developing capacity for its export growth by sticking to its current routine and structure. This impacts the firm's capability to be trained so that the firm only needs to bear relatively low costs while improving its financial performance. Chang \& Rhee (2011) also emphasize that firms with high export intensity show that firms can adapt to these foreign market demands. The high intensity of exports also helps firms get much experiential knowledge to make it easier for firms to capture the point of view of foreign customers so that exports can be maximized and improve firm performance. However, with the TCD effect, firm performance will decrease due to the firm's limited absorptive capacity.

On the other hand, there are different results of the influence on the second determinants of firm perfor-mance shown in the speed of growth in international commercial intensity, which do not have a significant effect on firm performance (Tobin's q). These results are supported by Chen et al. (2015). This is due to the low quality of disclosure by the issuer, which makes investors not fully aware of or trusting the implications of foreign earnings in the firm's value. Not to mention when firms manipulate their financial statements in order to improve the results of their financial performance and reduce investor confidence.

Speed of increasing commitment of resources to foreign activities in this study has an inverted $\mathrm{u}$-shaped effect on firm perfor- 
mance (return on assets). These results are in line with Mohr \& Batsakis (2017). A firm will get first-mover advantages be-cause the firm decides to act relatively earlier than its competitors, giving it a competitive advantage in the form of technological leadership, superior asset placement and creating buyer switching costs, access to distribution channels, firm's good reputation in the eyes of the community as well as customer trust which are firm's intangible resources to maintain its competitive advantage. Firms can create or get valuable resources that latecomers will find difficult to imitate in the market and place the firm in a better position to exploit its strategic resources (Lieberman \& Montgomery 1988, in Mohr \& Batsakis 2017). But when this speed is not controlled, the firm's performance will decrease. This is based on the TCD effect as this effect will arise when the firm is no longer able to accommodate its international knowledge and experience and apply it to the limited internal firm network.

The same result is also shown in the second deter-minant of firm performance, where the speed of in-creasing commitment of resources to foreign activities in this study has an inverted u-shaped effect on firm performance (Tobin's q). These results support Gozzi et al. (2008) that also proves the existence of a segmentation theory that explains that issuers will reduce their cost of capital to increase the market value of the firm's assets so that the firm's q increases. An increase in share capital will actually decrease the q-value of the firm when the cost of replacing assets is equal to its market value.

\section{CONCLUSION}

Based on the above research results, it can be con-cluded that speed of increasing the breadth of the in-ternational market, speed of growth in international commercial intensity, and speed of increasing com-mitment of resources to foreign activities have an inverted u-shaped effect on return on assets.
Mean-while, the speed of increasing the breadth international market has a u-shaped effect on Tobin's q, speed of growth in international commercial intensity has no significant effect on Tobin's q, and speed of increasing commitment of resources to foreign activities has an inverted u-shaped effect on Tobin's q.

For firms in the manufacturing sector listed on the Indonesia Stock Exchange, this research can be used as a basis for consideration to assess and decide a company's ability and capability to accelerate its internationalization activities without crossing its boundaries. This is done to avoid the effect of TCD, which reduces firm performance. All factors, such as speed of increasing the breadth of the international market, speed of growth in international commercial intensity, speed of increasing commitment of resources to foreign activities, firm size, and rhythm, need more attention to be integrated into the firm's international strategic policies in order to give a positive value to financial performance.

For future researchers, this study can provide a point of view on this topic, which is a multidimen-sional approach to firm performance. This research uses the research object in the form of manufacturing sector firms listed on the Indonesia Stock Exchange. Therefore, other researchers can investigate this topic on the other research object to see the consistency of the results and are more generalizable. The next researcher can specifically test the variables that fail to affect the dependent variable significantly. The speed of growth in international commercial intensity, firm age, regionalization, and rhythm are variables that need to be retested against the dependent variable with different research objects.

This study succeeds in proving that the TCD effect can affect firm performance so that the speed of internationalization has limits. In addition, this research is the second time using a multidimensional approach to the speed of internationalization after Hilmersson and Johanson (2016). It has different research results due to different re- 
search objects so that the following researchers can be retested to make this topic get stronger, clearer, and more valuable results for all parties.

Another limitation of this study is about potential endogeneity (e.g. Bascle 2008) among the concepts under examination. It becomes more plausible to think that the firm's historic performance somewhat influences internationalization's speed. This study, unfortunately, failed to control for such problems. Future studies are expected to compensate for this potential endogeneity bias, including more determinants of the variables. Following Hilmersson \& Johansson's (2016) advice, this study suggests an alternative idea to create further indepth qualitative research on this topic. Such approaches would also be more relevant in addressing an interesting avenue for future research on changes in the speed of firm internationalization and examining the determinants and consequences of the acceleration or deceleration multidimensional speed measures.

\section{REFERENCES}

Autio, E. Sapienza, H.J. \& Almeida, J.G. 2000. Effects of age at entry, knowledge intensity, and imitability on inter-national growth. Academy of Management Journal 43(5): 902-906.

Barkema, H.G. \& Vermeulen, F. 1998. International Ex-pansion Through Start-Up or Acquisition: A Learning Per-spective. Academy of Management Journal 41(1): 7-26.

Bascle, G. 2008. Controlling for endogeneity with instru-mental variables in strategic management research. Strategic Organization 6(3): 285-327.

Casillas, J.C. \& Acedo, F.J. 2013. Speed in the Interna-tionalization Process of the Firm. International Journal of Management Reviews 15(1): 15-29.

Chang, S.J. \& Rhee, J.H. 2011. Rapid FDI expansion and firm performance. Journal of International Business Studies 42(8): 979-994.

Chen, C. Lian, L. \& Lobo, G.J. 2015. Proceedings from EFMA '15. Internationalization and Market Valuation in an Emerging Economy: Evidence from China. Amsterdam, ND: Author.

Cohen, W. M. \& Levinthal, D.A. 1990. Absorptive capacity: A New Perspective on Learning and Innovation. Admin-istrative Science Quarterly 35(1): 128-135.

Dierickx, I. \& Cool, K. 1989. Asset Stock Accumulation and Sustainability of Competitive Advantage. Management Science 35(12): 1504-1511.
Doidge, C. Karolyi, A. Stulz, R. 2004. Why are firms that list in the U.S. worth more? Journal of Financial Economics 71(1): 205-238.

Dunning, J.H. \& Lundan, S. 2008. Multinational enterprises and the global economy. 2nd edition, Cheltenham: Edward Elgar.

Eriksson, K. Johanson, J. Majkgard, A. \& Sharma, D.D. 1997. Experiential knowledge and cost in the internationalization process. Journal of International Business Studies 28(2): 337-360.

Gozzi, J.C. Levine, R. \& Schmukler, S.L. 2008. Interna-tionalization and the evolution of corporate valuation. Jour-nal of Financial Economics 88(3): 607-632.

Helfat, C.E. \& Peteraf, M.A. 2003. The dynamic resource-based view: capability lifecycles. Strategic Management Journal 24(10): 997-1010.

Hilmersson, M. \& Johanson, M. 2016. Speed of SME In-ternationalization and Performance. Management Interna-tional Review 56(1): 67-94.

Jiang, R. J. Beamish, P.W. \& Makino, S. 2014. Time compression diseconomies in foreign expansion. Journal of World Business 49(1): 114-121.

Kagermann, et al. 2013. Recommendations for Implementing the Strategic Initiative Industrie 4.0. Berlin: Industrie 4.0 Working Group of Acatech.

Lieberman, M.B. \& Montgomery, D.B. 1988. Firstmover advantages. Strategic Management Journal 9(1): 41-58.

Mohr, A. \& Batsakis, G. 2017. Internationalization Speed and Firm Performance: A Study of the Market-Seeking Ex-pansion of Retail MNEs. Management International Re-view 57(2): 153177.

Oviatt, B.M. \& McDougall, P.P. 2005. Defining Interna-tional Entrepreneurship and Modeling the speed of Interna-tionalization. Entrepreneurship Theory and Practice 29(5): 537-554.

Penrose, E. 1959. The theory of the growth of the firm. Ox-ford: Oxford University Press.

Powell, K.S. 2014. From M-P to MA-P: Multinationality alignment and performance. Journal of International Busi-ness Studies 45(2): 211-226.

Strange, R. \& Zucchella, A. 2017. Industry 4.0, global value chains and international business. Multinational Business Review 25(3): 174-184.

Vermeulen, F. \& Barkema, H. 2002. Pace, rhythm, and scope: process dependence in building a profitable multinational corporation. Strategic Management Journal 23(7): 637-653.

Wagner, H. 2004. Internationalization speed and cost efficien-cy: evidence from Germany. International Business Review 13(4): 447-463.

Wernerfelt, B. 1984. A resource-based view of the firm. Stra-tegic Management Journal 5(2): 171180.

Zhou, C. 2018. Internationalization and performance: evi-dence from Chinese firms. Chinese Management Studies 12(1): 19-34. 